Research Paper

\title{
Correcting the Shrinkage Effects of Formalin Fixation and Tissue Processing for Renal Tumors: toward Standardization of Pathological Reporting of Tumor Size
}

\author{
Thu Tran1, Chandru P. Sundaram², Clinton D. Bahler², John N. Eble1, David J. Grignon¹, M. Francesca \\ Monn ${ }^{2}$, Novae B. Simper ${ }^{1}$, Liang Cheng ${ }^{1,2}{ }^{\bowtie}$ \\ 1. Department of Pathology and Laboratory Medicine, Indiana University School of Medicine, Indianapolis, IN, USA \\ 2. Department of Urology, Indiana University School of Medicine, Indianapolis, IN, USA
}

$\triangle$ Corresponding author: Liang Cheng, MD, Department of Pathology and Laboratory Medicine, Indiana University School of Medicine,

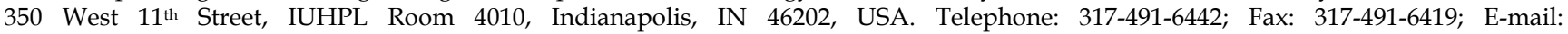
liang_cheng@yahoo.com

(C) 2015 Ivyspring International Publisher. Reproduction is permitted for personal, noncommercial use, provided that the article is in whole, unmodified, and properly cited. See http://ivyspring.com/terms for terms and conditions.

Received: 2015.03.10; Accepted: 2015.05.05; Published: 2015.07.02

\begin{abstract}
Given the importance of correctly staging renal cell carcinomas, specific guidelines should be in place for tumor size measurement. While a standard means of renal tumor measurement has not been established, intuitively, tumor size should be based on fresh measurements. We sought to assess the accuracy of postfixation and microscopic measurements of renal tumor size, as compared to fresh measurements and radiographic size. Thirty-four nephrectomy cases performed by a single surgeon were prospectively measured at different time points. The study cases included 23 clear cell renal cell carcinomas, 6 papillary renal cell carcinomas, and 5 other renal tumors. Radiologic tumors were $12.1 \%$ larger in diameter than fresh tumors $(P<0.01)$. Furthermore, fresh specimens were $4.6 \%$ larger than formalin-fixed specimens $(P<0.01)$, and postfixation measurements were $7.1 \%$ greater than microscopic measurements $(P<0.01)$. The overall mean percentage of shrinkage between fresh and histological specimens was $11.4 \%(P<0.01)$. Histological processing would cause a tumor stage shift from PTIb to pTla for two tumors in this study. The shrinkage effects of formalin fixation and histological processing may result in understaging of renal cell carcinomas. The shrinkage factor should be considered when reporting tumor size.
\end{abstract}

Key words: Kidney; renal cell carcinoma; tissue processing shrinkage; tumor size measurement; radiographic size; pathologic staging

\section{Introduction}

Kidney cancer is currently the sixth and eighth most common cause of new cancer diagnoses in American men and women, respectively, and the incidence has increased by approximately $3 \%$ annually.[1-5] In particular, the rate of renal cell carcinoma has steadily increased over the past several decades, and renal cell carcinomas are currently one of the most lethal tumors of the genitourinary system.[6] The tumor, nodes, and metastasis (TNM) staging system for renal cell carcinoma has evolved over the years in an effort to be more prognostically relevant as new research has emerged.[7-10] In 2002, the pT1 group was subdivided into a pT1a category for tumors measuring $4 \mathrm{~cm}$ or less and $\mathrm{pT} 1 \mathrm{~b}$ for larger tumors measuring up to $7 \mathrm{~cm}$. Recently, in 2010, the pT2 division was similarly refined with tumors measuring greater than 7 and up to $10 \mathrm{~cm}$ placed in a pT2a category, and those larger than $10 \mathrm{~cm}$ being staged as pT2b.[11] In the upcoming $4^{\text {th }}$ edition of the World Health Organization (WHO) Classification of Tumors of the Urinary System and Male Genital Organs, tumor size using $1.5 \mathrm{~cm}$ as a cutoff will be pro- 
posed to distinguish renal papillary adenoma from papillary renal cell carcinoma, though it is unclear if the tumor size should be based on fresh, postfixation, or microscopic measurement.

Given the fact that tumor size plays a key role in staging renal cell carcinomas, specific guidelines should be in place for tumor measurement.[6, 9-14] The TNM classification method has evolved from the nonspecific size distinctions of "small" and "large" to further subclassifications of specific tumor size cutoffs that may affect prognosis and treatment, but clear definitions of how to obtain these size measurements are lacking. [6, 9-14] We sought to quantify the effects of formalin fixation, tissue processing and mounting of histologic sections on tumor size in a prospective study.

\section{Materials and Methods}

From the period of October 3, 2013 to November 20, 2014, all nephrectomy cases performed by a single urologist (CPS) at our institution were prospectively measured at different time points. At the end of surgery, the fresh specimen was sectioned and measurements of the tumor's three dimensions were taken by the urologist (CPS) with the assistance of pathology assistants and surgical pathologists. The most representative cross-section that included the tumor's largest dimension was selected and marked with ink. In order to accurately measure the tumor histologically by whole mount, only postresection renal neoplasms grossly measuring $5.5 \mathrm{~cm}$ or less were included in the study. The kidney specimen was then placed in $10 \%$ formalin and allowed to fix for a time period ranging from 6 to 24 hours. After fixation, another set of three dimensional measurements were taken. Two-dimensional measurements of the selected cross-section were also recorded. The representative cross-section, along with the standard tissue sections taken for diagnosis and staging, underwent dehydration, clearing, paraffin wax embedding, section cutting, mounting, and staining with hematoxylin and eosin. A whole mount glass slide or standard glass slide section was made of the most representative cross-section, and two-dimensional tumor size was measured (TT) (Fig 1). All measurements were made using a plastic metric ruler at $1 \mathrm{~mm}$ precision. Tumors that were too large to fit a whole mount slide (fresh tumor size $>5.5 \mathrm{~cm}$ ), whose cross-sections did not include the largest dimension, or whose most representative cross-section was mistakenly incised and transferred to multiple slides were excluded. In addition, preoperative computerized tomography (CT) and magnetic resonance imaging (MRI) images were retrospectively reviewed (CDB) to obtain radiologic renal tumor measurements in three dimensions. Both axial and coronal/sagittal reformats were utilized in an effort to acquire the most accurate greatest dimension. All investigators were blinded to previously recorded measurements. Clinicopathologic information, including each patient's age, gender, type of surgery, tumor histologic subtype and pathologic staging classification, was recorded. Prior to the initiation of this prospective study, the protocol was reviewed and approved by the Indiana University Institutional Review Board. All local, state, and federal guidelines for the protection of human subjects were strictly maintained throughout the course of the study.
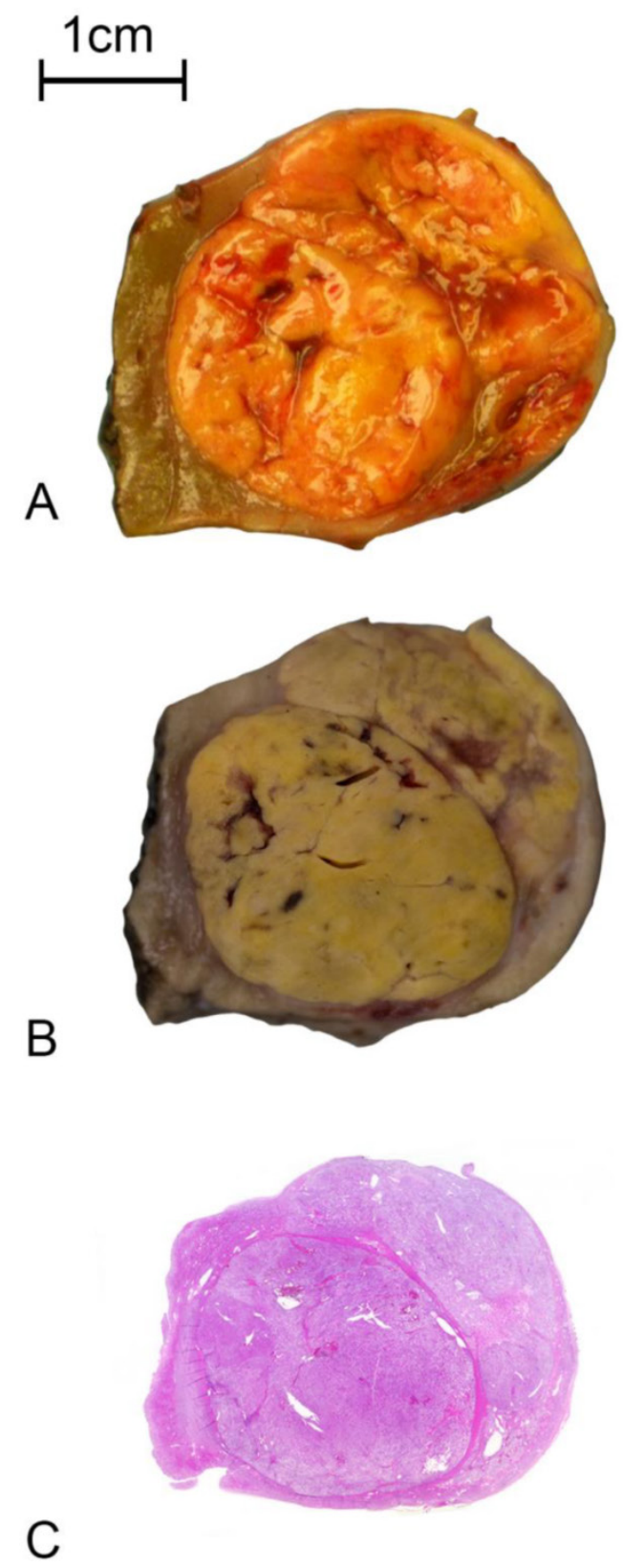

Figure 1. Pictorial representation of the sequential outcomes of renal tumor fixation and processing. A: The transversally sectioned renal tumor specimen immediately after resection; $\mathrm{B}$ : The corresponding transversally sectioned renal tumor specimen after fixation in 10\% formalin; and C: Microscopic section of the renal tumor specimen on a whole mount hematoxylin and eosin glass slide 
Descriptive statistics were utilized to describe differences in diameter between the four stages of measurement. Student $t$ test was used to compare the percentage of tumor shrinkage between each of the measurement groups. All statistical analyses were performed using STATA version 12.1 (Stata Corp. LP, College Station, TX) and $P$ values $<0.05$ were considered statistically significant. All $P$ values were two-sided.

Utilizing the resulting mean shrinkage values in tumor diameter between the three stages of measurement, corresponding conversion factors were calculated based on the formula: 1/(1-(shrinkage decimal)).[15]

\section{Results}

A total of 34 renal tumors were included in the study, which consisted of 23 clear cell renal cell carcinomas, 6 papillary renal cell carcinomas, 1 chromophobe renal cell carcinoma, $1 \mathrm{t}(6 ; 11)$ renal cell carcinoma, and 3 oncocytomas. All cases were partial nephrectomies from a total of 16 women and 18 men. The ages of the patients ranged from 37 to 84 years old with a mean age of 64 years. Two clear cell renal cell carcinomas were staged as pT3a. Two tumors, a clear cell and a chromophobe renal cell carcinoma, were staged as pT1b. The remaining tumors, except for the 3 oncocytomas, were staged as pT1a.

The tumor diameters for postresection (fresh) specimens ranged from 1-5.1 cm (average, $2.7 \mathrm{~cm}$ ) with 7 tumors measuring less than $2 \mathrm{~cm}, 23$ between 2-4 cm, and 4 larger than $4 \mathrm{~cm}$. Fixed tumor diameters ranged from 1-4.8 cm (average, $2.5 \mathrm{~cm}$ ) with 8 tumors measuring less than $2 \mathrm{~cm}, 22$ between $2-4 \mathrm{~cm}$, and 4 larger than $4 \mathrm{~cm}$. Microscopic tumor diameters ranged from 1-4.6 cm (average, $2.3 \mathrm{~cm}$ ), and 13 tumors measured less than $2 \mathrm{~cm}, 19$ between $2-4 \mathrm{~cm}$, and 2 larger than $4 \mathrm{~cm}$.

The average decrease in tumor diameter for fixed specimens, as compared to fresh, was $0.1 \mathrm{~cm}$ (range, $0-0.8 \mathrm{~cm})$ with a mean shrinkage of $4.6 \% \quad(P<0.01)$ (range, 0-18.2\%). Furthermore, the average decrease in diameter for histological specimens, as compared to fixed tumors, was $0.2 \mathrm{~cm}$ (range, $0-0.7 \mathrm{~cm}$ ) with a mean shrinkage of $7.1 \%(P<0.01)$ (range, $0-18.2 \%)$. The overall average decrease in tumor diameter between fresh and histological specimens was $0.3 \mathrm{~cm}$ (range, $0-1.1 \mathrm{~cm}$ ) with a mean shrinkage of $11.4 \%$ $(P<0.01)$ (range, $0-22.7 \%)$ (Fig 2).

CT and MRI scans were obtained at an average of 2.4 months before surgery. The tumor diameters based on radiologic imaging ranged from $1.5-5.7 \mathrm{~cm}$ (average, $3.0 \mathrm{~cm}$ ) with 5 tumors measuring less than 2 $\mathrm{cm}, 24$ between 2 and $4 \mathrm{~cm}$, and 5 larger than $4 \mathrm{~cm}$. Radiologic tumor diameters averaged $0.4 \mathrm{~cm}$ larger than fresh tumor diameters. This corresponds to a mean shrinkage of $12.1 \%$ between radiologic and postresection measurements.

Table 1 illustrates the utilization of our calculated correction factors. In terms of tumor diameter measurements, a conversion factor of 1.08 will account for shrinkage due to histological processing alone, 1.05 will correct formalin fixation shrinkage, and 1.13 will account for shrinkage from both fixation and tissue processing. Table 2 is a conversion table that provides precalculated fixed and fresh tumor diameters based on microscopic measurements, utilizing the aforementioned correction factors.

Table 1. Formulae for correcting measurements of renal cell carcinomas taken outside of the postresection (fresh) state $\S$

\begin{tabular}{lll}
\hline Tumor Diameter (D) & & \\
\hline $\begin{array}{l}\text { Microscopic Measure- } \\
\text { ment }\end{array}$ & Postfixation Size & Fresh Size \\
\hline $\mathrm{A}_{\mathrm{D}}^{*}$ & $\mathrm{~A}_{\mathrm{D}} \times 1.08$ & $\mathrm{~A}_{\mathrm{D}} \times 1.13$ \\
& $\mathrm{~B}_{\mathrm{D}}^{\dagger}$ & $\mathrm{B}_{\mathrm{D}} \times 1.05$ \\
\hline
\end{tabular}

$\S$ See the Methods section for the description of correction factor calculations

${ }^{*} \mathrm{~A}$ : Size of renal tumor as measured on glass slides

${ }^{\ddagger} \mathrm{B}$ : Size of renal tumor as measured grossly, post-formalin fixation

Table 2. Conversion table for renal cell carcinoma diameter measurements taken outside of the postresection (fresh) state

\begin{tabular}{|c|c|c|}
\hline $\begin{array}{l}\text { Microscopic Tumor } \\
\text { Measurement }\end{array}$ & Postfixation Tumor Size & Fresh Tumor Size \\
\hline $1.0 \mathrm{~cm}$ & $1.1 \mathrm{~cm}$ & $1.1 \mathrm{~cm}$ \\
\hline $1.2 \mathrm{~cm}$ & $1.3 \mathrm{~cm}$ & $1.4 \mathrm{~cm}$ \\
\hline $1.4 \mathrm{~cm}$ & $1.5 \mathrm{~cm}$ & $1.6 \mathrm{~cm}$ \\
\hline $1.6 \mathrm{~cm}$ & $1.7 \mathrm{~cm}$ & $1.8 \mathrm{~cm}$ \\
\hline $1.8 \mathrm{~cm}$ & $1.9 \mathrm{~cm}$ & $2.0 \mathrm{~cm}$ \\
\hline $2.0 \mathrm{~cm}$ & $2.2 \mathrm{~cm}$ & $2.3 \mathrm{~cm}$ \\
\hline $2.2 \mathrm{~cm}$ & $2.4 \mathrm{~cm}$ & $2.5 \mathrm{~cm}$ \\
\hline $2.4 \mathrm{~cm}$ & $2.6 \mathrm{~cm}$ & $2.7 \mathrm{~cm}$ \\
\hline $2.6 \mathrm{~cm}$ & $2.8 \mathrm{~cm}$ & $2.9 \mathrm{~cm}$ \\
\hline $2.8 \mathrm{~cm}$ & $3.0 \mathrm{~cm}$ & $3.2 \mathrm{~cm}$ \\
\hline $3.0 \mathrm{~cm}$ & $3.2 \mathrm{~cm}$ & $3.4 \mathrm{~cm}$ \\
\hline $3.2 \mathrm{~cm}$ & $3.5 \mathrm{~cm}$ & $3.6 \mathrm{~cm}$ \\
\hline $3.4 \mathrm{~cm}$ & $3.7 \mathrm{~cm}$ & $3.8 \mathrm{~cm}$ \\
\hline $3.6 \mathrm{~cm}$ & $3.9 \mathrm{~cm}$ & $4.1 \mathrm{~cm}$ \\
\hline $3.8 \mathrm{~cm}$ & $4.1 \mathrm{~cm}$ & $4.3 \mathrm{~cm}$ \\
\hline $4.0 \mathrm{~cm}$ & $4.3 \mathrm{~cm}$ & $4.5 \mathrm{~cm}$ \\
\hline $4.2 \mathrm{~cm}$ & $4.5 \mathrm{~cm}$ & $4.7 \mathrm{~cm}$ \\
\hline $4.4 \mathrm{~cm}$ & $4.8 \mathrm{~cm}$ & $5.0 \mathrm{~cm}$ \\
\hline $4.6 \mathrm{~cm}$ & $5.0 \mathrm{~cm}$ & $5.2 \mathrm{~cm}$ \\
\hline $4.8 \mathrm{~cm}$ & $5.2 \mathrm{~cm}$ & $5.4 \mathrm{~cm}$ \\
\hline $5.0 \mathrm{~cm}$ & $5.4 \mathrm{~cm}$ & $5.7 \mathrm{~cm}$ \\
\hline $5.2 \mathrm{~cm}$ & $5.6 \mathrm{~cm}$ & $5.9 \mathrm{~cm}$ \\
\hline $5.4 \mathrm{~cm}$ & $5.8 \mathrm{~cm}$ & $6.1 \mathrm{~cm}$ \\
\hline $5.6 \mathrm{~cm}$ & $6.0 \mathrm{~cm}$ & $6.3 \mathrm{~cm}$ \\
\hline $5.8 \mathrm{~cm}$ & $6.3 \mathrm{~cm}$ & $6.6 \mathrm{~cm}$ \\
\hline $6.0 \mathrm{~cm}$ & $6.5 \mathrm{~cm}$ & $6.8 \mathrm{~cm}$ \\
\hline $6.2 \mathrm{~cm}$ & $6.7 \mathrm{~cm}$ & $7.0 \mathrm{~cm}$ \\
\hline $6.4 \mathrm{~cm}$ & $6.9 \mathrm{~cm}$ & $7.2 \mathrm{~cm}$ \\
\hline $6.6 \mathrm{~cm}$ & $7.1 \mathrm{~cm}$ & $7.5 \mathrm{~cm}$ \\
\hline $6.8 \mathrm{~cm}$ & $7.3 \mathrm{~cm}$ & $7.7 \mathrm{~cm}$ \\
\hline $7.0 \mathrm{~cm}$ & $7.6 \mathrm{~cm}$ & $7.9 \mathrm{~cm}$ \\
\hline
\end{tabular}




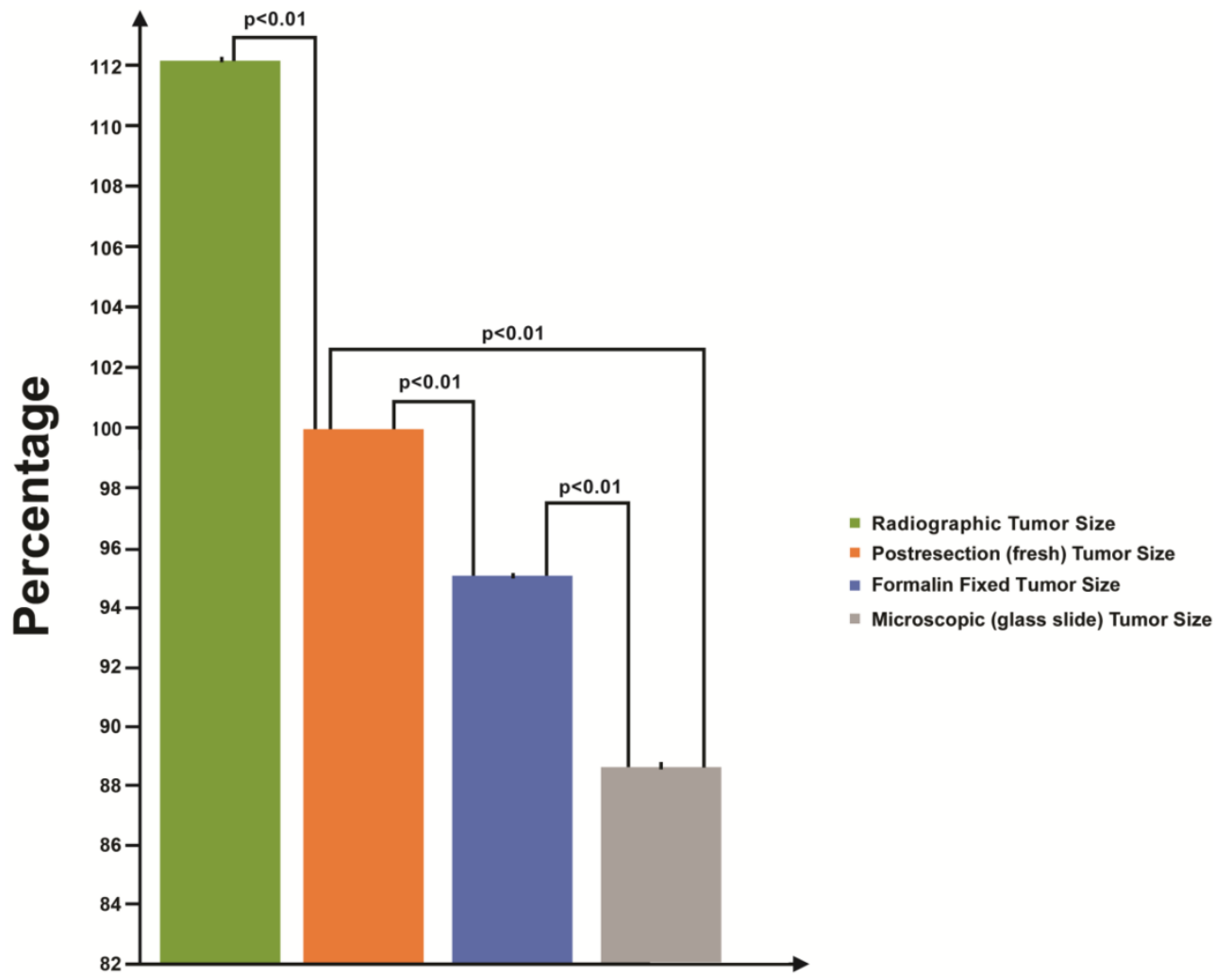

Figure 2. Average linear shrinkage in tumor diameter from radiologic imaging to final processed state. Tumor size relative to postresection (fresh) diameter is illustrated here. Fresh tumors (orange) are considered the gold standard in terms of size and are represented as $100 \%$ of the diameter. Mean radiologic (green), postfixation (blue), and microscopic glass slide (gray) measurements are represented as percentage differences from the gold standard. Standard error bars and $P$ values between each group pairing are provided. $Y$ axis represents tumor size relative to postresection diameter.

\section{Discussion}

Since the inception of staging systems for renal cell carcinomas and their evolution over the past 50 years, staging remains an important prognostic indicator.[6, 9-14] The first classification method was introduced by Flocks and Kadesky in 1958, which concentrated on the extent of tumor spread.[16] The TNM staging system was established in 1978 and introduced tumor size as a prognostic factor.[10, 11] The TNM system for renal cell carcinoma has been revised multiple times to be more prognostically precise, changing the T2 tumor size cutoff points from "large" to greater than $2 \mathrm{~cm}$ and then to greater than $7 \mathrm{~cm}$. [6, 9-14] In addition, T1 and T2 tumors were each further subcategorized into "a" and " $b$ " stages by the TNM system with the cutoffs placed at $4 \mathrm{~cm}$ and $10 \mathrm{~cm}$, respectively.[10, 11] Tumor size has repeatedly been shown to be a significant prognostic indicator, even independent of pathologic stage.[8, 17] Larger renal cell carcinomas are significantly more likely to have renal sinus invasion, ipsilateral adrenal involvement, synchronous metastasis, and an overall decreased 5-year survival rate.[18-22] According to Bonsib and Bhalodia, unrecognized retrograde vein invasion may have partially contributed to the reportedly worse prognosis associated with larger renal tumors, whose size may have been inflated with confluent nodules of intravenous cancer.[23] Correct renal tumor measurement remains essential for accurate prognostication.

Tumor size plays a key role in renal cell carcinoma staging, and its importance has grown throughout TNM's evolution with the additions of further subdivisions according to size.[6, 9-14] Despite this, a standardized means of tumor measurement has not been established. While, intuitively, staging a renal cell carcinoma should be based on fresh tumor measurements, most pathologists report size based on postfixation or, for small tumors, microscopic measurements.

Our results demonstrate that formalin fixation can shrink renal tumors, and the steps of histological processing, embedding and mounting cause even further tumor shrinkage. Formalin acts by diffusing through the tissue and binding to amino groups, precipitating the formation of an extensive network of cross-linked proteins and nucleic acids, which can cause histological changes, such as cell shrinkage and distortion.[24] Conceivably, these cellular changes can 
have a global effect on the whole tissue specimen. While the effects of fixation and histological processing on specimen size have not been previously systematically studied in the kidney, there are a small number of similar studies performed on other organ systems. Several of these studies also found a shrinkage effect of formalin for various tissue specimens. Our mean $4.6 \%$ tumor diameter shrinkage after fixation is greater than the $2.7 \%$ found for cervical tissue, but smaller than that reported in most studies, which have ranged from approximately $8-20 \%$.[25-31] This formalin-induced shrinkage effect occurred in a range of specimens, including those from the lung, gastrointestinal system, oral cavity, vulva and breast.[24, 26-33] This has not been consistent, however, with several studies reporting no shrinkage after fixation for skin, breast and gastrointestinal specimens.[34-41] One paper found an increase in one dimension for forelimb specimens, which flattened due to gravity after formalin fixation, causing an increase in width, but a decrease in height.[42] The varying study results may be explained by the different types of tissues and tumors along with differences in formalin concentration and fixation time.

A small subset of studies has evaluated the effects of histological processing. After formalin fixation, there are several steps that may affect tissue size as the tissue section progresses to the final staining phase. Tissue shrinkage may occur as the section undergoes alcohol dehydration.[15] In addition, during the embedding stage, the tissue may be compressed if the paraffin is too warm and undergo extra shrinkage during the cooling process. During section cutting, a loose or off-angled microtome knife may result in tissue compression or chatter, and the tissue may not evenly spread in a cool water bath during the mounting stage.[39] In our study, the average percentage of shrinkage in tumor diameter from the fixed to the histological states was $7.1 \%$, and the overall mean shrinkage was $11.4 \%$ between the fresh and microscopic measurements. In the previously published studies, the percentage of shrinkage from the fixed to the microscopic measurements ranged from approximately $10 \%$ to $27 \%$, and the overall percentage of shrinkage from fresh to microscopic measurements ranged from $4.5 \%$ to $41 \%$. [15, 25, 31, 32, 39] The tissue types studied included cervical, gastrointestinal, prostatic, breast and oral cavity specimens. Pritt et al. found both substantial increases and decreases in breast tumor size with histological processing, and Johnson et al. reported that mucosal margins of oral cavity specimens did not change with slide preparation, but the deep muscular margin shrank by $9.8 \%$. [27, 39] Variations in tissue type and, even more so, in laboratory practices and processes, such as dif- ferences in water bath temperature and the time tissue sections spend in warm water[15] or the practice of sectioning suboptimally fixed and processed tissue [39], may explain the varying findings.

The subjects of the published studies are highly variable and include animal models, non-neoplastic tissue, and human tumors ranging from skin to breast malignancies. While studying animals and normal tissues may provide useful background information, research involving human tumors would have the most impact on patient care. Certain tumors, though, such as breast carcinomas, may have significant infiltration that can be difficult to gauge during gross tumor measurement. Such measurements may underestimate the true size of the neoplasm. Other tumors, such as lung and colorectal carcinomas, may be too large to lend feasibility to studies comparing fresh and fixed measurements with microscopic measurements. Renal neoplasms, on the other hand, offer an ideal model for tumor measurement analysis due to their easily visualized, often circumscribed, and unifocal nature. In addition, the steady increase in renal cell carcinoma incidence due to the detection of small incidental kidney tumors by routine radiological studies translates to the finding that many renal tumors are small enough to offer a complete, representative cross-section on a standard glass or whole mount slide.[43] The kidney is also a dense, solid, encapsulated organ that is neither characterized by the elasticity of skin and the gastrointestinal tract, nor the almost semisolid nature of adipose tissue. Hence, the kidney often preserves the renal tumor's overall configuration, whether solid or cystic, after removal and fixation. On the other hand, differences in renal tumor architecture, including the presence of fibrosis, cystic change, hemorrhage, and necrosis, may affect the extent of shrinkage. To the best of the authors' knowledge, our study is the first to describe renal tumors as a model for postfixation and processing shrinkage analysis.

Irrespective of the differences in subject matter and tissue types of the published reports, many of these studies were implemented because tumor size or margin status is essential for staging and prognosis in their respective organ systems, and most staging systems do not specify the method for measurement. For kidney tumors in particular, our results emphasize the importance of establishing a standard means of tumor measurement. Two of our cases would receive a different pT1 classification depending on which measurement was used for staging. Tumor size has repeatedly been shown to be a significant prognostic indicator.[8] Larger renal cell carcinomas included in the $\mathrm{T} 1 \mathrm{~b}$ category are significantly more likely to have renal sinus invasion, ipsilateral adrenal 
involvement, synchronous metastasis, and an overall decreased 5-year survival rate.[18-21] Given the importance of correctly staging renal cell carcinomas, specific guidelines should be in place for tumor measurement. Intuitively, renal tumors should be measured before placement in formalin for the most accurate tumor staging. However, studies reporting on the prognostic significance of tumor size frequently do not specify how or when measurements were obtained. $[9,44]$

Due to the fact that taking fresh tumor measurements may not always be convenient or feasible, a conversion factor would be a useful tool for practicing pathologists. For example, Silverman et al. found $20 \%$ shrinkage of melanoma excisions after fixation. Because minimum margins are essential for treatment, the authors calculated a formula to estimate in vivo margins from fixed-tissue measurements for melanoma excisions. [45] Furthermore, in the prostate, tumor volume is an essential staging and prognostic indicator.[15] Tissue shrinkage from processing has long been recognized and various correction factors have been proposed for accurate tumor volume calculations, ranging from 1.14-1.5.[46, 47] The methods that engendered these prostate volume correction factors varied and included computer planimetry, water displacement, transrectal ultrasound, and direct measurements.[46, 47] In terms of the kidney, our results demonstrate an average $4.6 \%$ shrinkage in diameter between fresh and fixed tumor measurements, $7.1 \%$ between fixed and glass slide measurements, and $11.4 \%$ between fresh and glass slide measurements, which correlate to correction factors of $1.05,1.08$, and 1.13, respectively. The following example illustrates the correction of shrinkage effects on a kidney tumor that measures $2 \mathrm{~cm}$ on the glass slide. By using the linear conversion factors, the postfixation diameter would equate to $2.2 \mathrm{~cm}$ and the postresection diameter $2.3 \mathrm{~cm}$ (Table 2). While fresh tumors measuring greater than $5.5 \mathrm{~cm}$ were excluded from the study due to decreased accuracy in terms of histologic measurement, the conversion factors may be applicable for such tumors and the measurements were extrapolated and also provided in Table 2.

Papillary adenomas of the kidney are defined as small, low grade, unencapsulated tumors with papillary or tubular architecture that measure no larger than $1.5 \mathrm{~cm}$. This size cutoff will be proposed in the upcoming $4^{\text {th }}$ edition of the WHO Classification of Tumors of the Urinary System and Male Genital Organs, but the method of measurement remains undefined. If one were to apply the correction factors to a renal papillary tumor measuring $1.4 \mathrm{~cm}$ in diameter on the glass slide, the corresponding postfixation diameter would equal $1.5 \mathrm{~cm}$ and postresection di- ameter $1.6 \mathrm{~cm}$ (Table 2). Using the microscopic measurement, the tumor in our example would be diagnosed as a papillary adenoma. But by utilizing the conversion factor to account for shrinkage from the fresh state, the tumor could be diagnosed as a papillary renal cell carcinoma. Currently, small papillary tumors of the kidney are likely to be diagnosed using gross, postfixation or microscopic measurements. When the definition of a benign tumor versus a malignant neoplasm is so narrow, correction factors are especially pertinent for accurate diagnosis.

Kidney tumors provide an ideal model to analyze the shrinkage effects of fixation and processing. Our results suggest that renal cell carcinomas with diameters at TNM staging thresholds may be understaged if postfixation or microscopic measurements are utilized. Use of a correction factor may prevent such errors. For renal tumors, we recommend using a tumor diameter conversion factor of 1.05 for postfixation gross measurements or 1.13 for microscopic measurements to approximate the fresh tumor size more accurately. Furthermore, with an average difference of $12.1 \%$ in diameter, our results demonstrate that tumor measurements based on radiologic imaging may overestimate the size of renal neoplasms when compared to the gold standard (fresh) measurements. Our outcomes are in line with those of previous studies that found radiographic measurements of renal masses to be larger than pathologic measurements, especially for smaller tumors.[48-58] While the size differences between radiologic and pathologic measurements may be statistically significant in a majority of these studies, the clinical significance in terms of treatment outcomes is uncertain.[49, $52,53,57]$ Nevertheless, the utilization of correction factors for pathologic specimens would increase accuracy for correlations with presurgical imaging measurements often used in clinical studies. Most importantly, conversion factors would be valuable for the placement of renal cell carcinomas in the appropriate pathologic tumor stage.

While a standard means of renal tumor measurement has not been established, intuitively, tumor size should be based on fresh measurements. The shrinkage effects of formalin fixation and histological processing may result in understaging of renal cell carcinomas. It would be helpful if future reports of the prognostic significance of pathologic stage for renal cell carcinomas included details on the method for tumor size measurement, especially for small renal tumors. 


\section{Abbreviations}

CT: computerized tomography; MRI: magnetic resonance imaging; TNM: tumor, nodes, and metastasis; WHO: World Health Organization

\section{Competing Interests}

The authors have declared that no competing interest exists.

\section{References}

1. [Internet] American Cancer Society. Cancer Facts and Figures 2015. http://www.cancer.org/acs/groups/content/@editorial/documents/docum ent/acspc-044552.pdf

2. Sun M, Thuret R, Abdollah F, Lughezzani G, Schmitges J, Tian Z, et al. Age-adjusted incidence, mortality, and survival rates of stage-specific renal cell carcinoma in North America: a trend analysis. Eur Urol. 2011;59(1):135-41.

3. Torre LA, Bray F, Siegel RL, Ferlay J, Lortet-Tieulent J, Jemal A. Global cancer statistics, 2012. CA Cancer J Clin. 2015;65(2):87-108.

4. Siegel RL, Miller KD, Jemal A. Cancer statistics, 2015. CA Cancer J Clin. 2015;65(1):5-29.

5. [Internet] Altekruse SF, Kosary CL, Krapcho M, Neyman N, Aminou R, Waldron W, et al. SEER Cancer Statistics Review, 1975-2007, National Cancer Institute. Bethesda, MD. http://seer.cancer.gov/csr/1975 2007/

6. Bostwick DG, Cheng L. Urologic Surgical Pathology. Third edition. Philadelphia, PA: Elsevier/Saunders; 2014.

7. Brookman-May S, May M, Zigeuner R, Shariat SF, Scherr DS, Chromecki T, et al. Collecting system invasion and Fuhrman grade but not tumor size facilitate prognostic stratification of patients with pT2 renal cell carcinoma. J Urol. 2011;186(6):2175-81.

8. Delahunt B. Advances and controversies in grading and staging of renal cell carcinoma. Mod Pathol. 2009;22 Suppl 2:S24-36.

9. Novara G, Ficarra V, Antonelli A, Artibani W, Bertini R, Carini M, et al. Validation of the 2009 TNM version in a large multi-institutional cohort of patients treated for renal cell carcinoma: are further improvements needed? Eur Urol. 2010;58(4):588-95.

10. Meskawi M, Sun M, Trinh QD, Bianchi M, Hansen J, Tian Z, et al. A review of integrated staging systems for renal cell carcinoma. Eur Urol. 2012;62(2):303-14.

11. Eggener S. TNM staging for renal cell carcinoma: time for a new method. Eur Urol. 2010;58(4):517-9; discussion 9-21.

12. Brookman-May SD, May M, Wolff I, Zigeuner R, Hutterer GC, Cindolo L, et al. Evaluation of the Prognostic Significance of Perirenal Fat Invasion and Tumor Size in Patients with pT1-pT3a Localized Renal Cell Carcinoma in a Comprehensive Multicenter Study of the CORONA project. Can We Improve Prognostic Discrimination for Patients with Stage pT3a tumors? Eur Urol. 2015;67(5):943-51.

13. Waalkes S, Becker F, Schrader AJ, Janssen M, Wegener G, Merseburger AS, et al. Is there a need to further subclassify pT2 renal cell cancers as implemented by the revised 7th TNM version? Eur Urol. 2011;59(2):258-63.

14. Escudier B, Porta C, Schmidinger M, Algaba F, Patard JJ, Khoo V, et al. Renal cell carcinoma: ESMO Clinical Practice Guidelines for diagnosis, treatment and follow-up. Ann Oncol. 2014;25 Suppl 3:iii49-56.

15. Jonmarker S, Valdman A, Lindberg A, Hellstrom M, Egevad L. Tissue shrinkage after fixation with formalin injection of prostatectomy specimens. Virchows Arch. 2006;449(3):297-301.

16. Flocks RH, Kadesky MC. Malignant neoplasms of the kidney; an analysis of 353 patients followed five years or more. J Urol. 1958;79(2):196-201.

17. Ficarra V, Galfano A, Mancini M, Martignoni G, Artibani W. TNM staging system for renal-cell carcinoma: current status and future perspectives. Lancet Oncol. 2007;8(6):554-8.

18. Bonsib SM. T2 clear cell renal cell carcinoma is a rare entity: a study of 120 clear cell renal cell carcinomas. J Urol. 2005;174(4 Pt 1):1199-202; discussion 202.

19. Ito K, Nakazawa H, Marumo K, Ozono S, Igarashi T, Shinohara N, et al. Risk factors for ipsilateral adrenal involvement in renal cell carcinoma. Urology. 2008;72(2):354-8

20. Lughezzani G, Jeldres C, Isbarn H, Perrotte P, Shariat SF, Sun M, et al. Tumor size is a determinant of the rate of stage $\mathrm{T} 1$ renal cell cancer synchronous metastasis. J Urol. 2009;182(4):1287-93.

21. Lam JS, Shvarts O, Leppert JT, Figlin RA, Belldegrun AS. Renal cell carcinoma 2005: new frontiers in staging, prognostication and targeted molecular therapy. J Urol. 2005;173(6):1853-62.

22. Karakiewicz PI, Lewinshtein DJ, Chun FK, Briganti A, Guille F, Perrotte P, et al. Tumor size improves the accuracy of TNM predictions in patients with renal cancer. Eur Urol. 2006;50(3):521-8; discussion 9.

23. Bonsib SM, Bhalodia A. Retrograde venous invasion in renal cell carcinoma: a complication of sinus vein and main renal vein invasion. Mod Pathol. 2011;24(12):1578-85.
24. Hsu PK, Huang HC, Hsieh CC, Hsu HS, Wu YC, Huang MH, et al. Effect of formalin fixation on tumor size determination in stage I non-small cell lung cancer. Ann Thorac Surg. 2007;84(6):1825-9.

25. Boonstra H, Oosterhuis JW, Oosterhuis AM, Fleuren GJ. Cervical tissue shrinkage by formaldehyde fixation, paraffin wax embedding, section cutting and mounting. Virchows Arch A Pathol Anat Histopathol. 1983;402(2):195-201.

26. Gopalswamy N, Shenoy VN, Choudhry U, Markert RJ, Peace N, Bhutani MS, et al. Is in vivo measurement of size of polyps during colonoscopy accurate? Gastrointest Endosc. 1997;46(6):497-502.

27. Johnson RE, Sigman JD, Funk GF, Robinson RA, Hoffman HT. Quantification of surgical margin shrinkage in the oral cavity. Head Neck. 1997;19(4):281-6.

28. Palaia I, Bellati F, Calcagno M, Musella A, Perniola G, Panici PB. Invasive vulvar carcinoma and the question of the surgical margin. Int J Gynaecol Obstet. 2011;114(2):120-3.

29. Siu KF, Cheung HC, Wong J. Shrinkage of the esophagus after resection for carcinoma. Ann Surg. 1986;203(2):173-6.

30. Verma VP, Kaur N, Agarwal N, Bhargava SK, Singh UR, Saha S, et al. Intra-operative measurement of tumour size in breast cancer and its comparison with other methods: a prospective study. Ecancermedicalscience. 2008;2:96.

31. Watanabe M, Kida M, Yamada Y, Saigenji K. Measuring tumor volume with three-dimensional endoscopic ultrasonography: an experimental and clinical study (including video). Endoscopy. 2004;36(11):976-81.

32. Eid I, El-Muhtaseb MS, Mukherjee R, Renwick R, Gardiner DS, Macdonald A. Histological processing variability in the determination of lateral resection margins in rectal cancer. J Clin Pathol. 2007;60(6):593-5.

33. Turner JK, Wright M, Morgan M, Williams GT, Dolwani S. A prospective study of the accuracy and concordance between in-situ and postfixation measurements of colorectal polyp size and their potential impact upon surveillance. Eur J Gastroenterol Hepatol. 2013;25(5):562-7.

34. Blasdale C, Charlton FG, Weatherhead SC, Ormond P, Lawrence CM. Effect of tissue shrinkage on histological tumour-free margin after excision of basal cell carcinoma. Br J Dermatol. 2010;162(3):607-10.

35. Dauendorffer JN, Bastuji-Garin S, Guero S, Brousse N, Fraitag S. Shrinkage of skin excision specimens: formalin fixation is not the culprit. Br J Dermatol. 2009;160(4):810-4.

36. Golomb FM, Doyle JP, Grin CM, Kopf AW, Silverman MK, Levenstein MJ. Determination of preexcision surgical margins of melanomas from fixed-tissue specimens. Plast Reconstr Surg. 1991;88(5):804-9.

37. Krekel NM, van Slooten HJ, Barbe E, de Lange de Klerk ES, Meijer S, van den Tol MP. Is breast specimen shrinkage really a problem in breast-conserving surgery? J Clin Pathol. 2012;65(3):224-7.

38. Mendez Romero A, Verheij J, Dwarkasing RS, Seppenwoolde Y, Redekop WK, Zondervan PE, et al. Comparison of macroscopic pathology measurements with magnetic resonance imaging and assessment of microscopic pathology extension for colorectal liver metastases. Int J Radiat Oncol Biol Phys. 2012;82(1):159-66.

39. Pritt B, Tessitore JJ, Weaver DL, Blaszyk H. The effect of tissue fixation and processing on breast cancer size. Hum Pathol. 2005;36(7):756-60.

40. Schoen RE, Gerber LD, Margulies C. The pathologic measurement of polyp size is preferable to the endoscopic estimate. Gastrointest Endosc. 1997;46(6):492-6.

41. Vent J, Zimmermann C, Drebber U, Wedemeyer I, Eckel HE, Huettenbrink KB, et al. Influence of formalin fixation on tissue dimensions in palatal tonsils. Pathol Res Pract. 2014;210(1):59-61.

42. Docquier PL, Paul L, Cartiaux O, Lecouvet F, Dufrane D, Delloye C, et al. Formalin fixation could interfere with the clinical assessment of the tumor-free margin in tumor surgery: magnetic resonance imaging-based study. Oncology. 2010;78(2):115-24

43. Klatte T, Patard JJ, de Martino M, Bensalah K, Verhoest G, de la Taille A, et al. Tumor size does not predict risk of metastatic disease or prognosis of small renal cell carcinomas. J Urol. 2008;179(5):1719-26.

44. Kim SP, Alt AL, Weight CJ, Costello BA, Cheville JC, Lohse C, et al. Independent validation of the 2010 American Joint Committee on Cancer TNM classification for renal cell carcinoma: results from a large, single institution cohort. J Urol. 2011;185(6):2035-9.

45. Silverman MK, Golomb FM, Kopf AW, Grin-Jorgensen CM, Vossaert KA, Doyle JP, et al. Verification of a formula for determination of preexcision surgical margins from fixed-tissue melanoma specimens. J Am Acad Dermatol. 1992;27(2 Pt 1):214-9.

46. McNeal JE. Prostate cancer volume. Am J Surg Pathol. 1997;21(11):1392-3

47. Schned AR, Wheeler KJ, Hodorowski CA, Heaney JA, Ernstoff MS, Amdur RI, et al. Tissue-shrinkage correction factor in the calculation of prostate cancer volume. Am J Surg Pathol. 1996;20(12):1501-6.

48. Alicioglu B, Kaplan M, Yurut-Caloglu V, Usta U, Levent S. Radiographic size versus surgical size of renal masses: which is the true size of the tumor? J BUON. 2009;14(2):235-8.

49. Chen W, Wang L, Yang Q, Liu B, Sun Y. Comparison of radiographic and pathologic sizes of renal tumors. Int Braz J Urol. 2013;39(2):189-94.

50. Herr HW. Radiographic vs surgical size of renal tumours after partial nephrectomy. BJU Int. 2000;85(1):19-21.

51. Herr HW, Lee CT, Sharma S, Hilton S. Radiographic versus pathologic size of renal tumors: implications for partial nephrectomy. Urology. 2001;58(2):157-60. 
52. Kurta JM, Thompson RH, Kundu S, Kaag M, Manion MT, Herr HW, et al. Contemporary imaging of patients with a renal mass: does size on computed tomography equal pathological size? BJU Int. 2009;103(1):24-7.

53. Lee SE, Lee WK, Kim DS, Doo SH, Park HZ, Yoon CY, et al. Comparison of radiographic and pathologic sizes of renal tumors. World J Urol. 2010;28(3):263-7.

54. Schlomer B, Figenshau RS, Yan Y, Bhayani SB. How does the radiographic size of a renal mass compare with the pathologic size? Urology. 2006;68(2):292-5.

55. Choi JY, Kim BS, Kim TH, Yoo ES, Kwon TG. Correlation between Radiologic and Pathologic Tumor Size in Localized Renal Cell Carcinoma. Korean J Urol. 2010;51(3):161-4.

56. Choi SM, Choi DK, Kim TH, Jeong BC, Seo SI, Jeon SS, et al. A Comparison of Radiologic Tumor Volume and Pathologic Tumor Volume in Renal Cell Carcinoma (RCC). PLoS One. 2015;10(3):e0122019.

57. Jeffery NN, Douek N, Guo DY, Patel MI. Discrepancy between radiological and pathological size of renal masses. BMC Urol. 2011;11:2.

58. Mucksavage P, Kutikov A, Magerfleisch L, Van Arsdalen K, Wein AJ, Ramchandani $\mathrm{P}$, et al. Comparison of radiographical imaging modalities for measuring the diameter of renal masses: is there a sizeable difference? BJU Int. 2011;108(8 Pt 2):E232-6. 